uous erythropoietin receptor activator (CERA) in patients with chronic kidney disease / Macdougall I. C., Robson R., Opatrna S., Liogier X., Pannier A., [et al.] // Clin J Am Soc Nephrol. - 2006. V. 1. - P. 1211-1215.

12. National Kidney Foundation. KDOQI Clinical Practice Guideline for Diabetes and CKD: 2012 Update. / AJKD. - 2012. - V. 60. - P. 850-886.

13. Ohashi N. Methoxy polyethylene glycol-epoetin beta for anemia with chronic kidney disease / Ohashi N., Sakao Y., Yasuda H., Kato A., Fujigaki Y. // Int J Nephrol Renov Dis. - 2012. - V. 5. P. 53-60.

14. Panichi $V$. Anaemia and resistance to erythropoiesis-stimulating agents as prognostic factors in hae- modialysis patients: results from the RISCAVID study / Panichi V., Rosati A., Bigazzi R., [et al.] // Nephrol Dial Transplant. - 2011. - V. 26. P. 2641-2648.

15. Roche. Mircera (methoxy polyethylene glycol-epoetin beta) - Product Information, 2011.

16. Sang-Ryol Ryu. The Prevalence and Management of Anemia in Chronic Kidney Disease Patients: Result from the Korea N Cohort Study for Outcomes in Patients With Chronic Kidney Disease (KNOW-CKD) / Sang-Ryol Ryu, Sue K. Park, Ji Yong Jung, [et al.] // J Korean Med Sci. - 2017. V. 32(2). - Р. 249-256.

Надійшла до редакції 27.01.2017 Прийнята до друку 03.03.2017

(с) Сташевська Н.В., Король Л.В., Мигаль Л.Я., Степанова Н.М., 2017

УДК: 616.61-002.3-036.87:616.34:577.1

Н.В. СТАШЕВСЬКА, Л.В. КОРОЛЬ, Л.Я. МИГАЛЬ, Н.М. СТЕПАНОВА

РОЛЬ ІНДИГЕННОЇ МІКРОБІОТИ КИШКІВНИКА У РОЗВИТКУ ОКСИДАТИВНОГО СТРЕСУ У ЖІНОК З РЕЦИДИВУЮЧИМ ПІЕЛОНЕФРИТОМ

\author{
NV STASHEVSKYI, LV KING, L. MYHAL, NM STEPANOVA
}

\title{
THE ROLE OF GUT INDIGENOUS MICROBIOTA IN THE DEVELOPMENT OF OXIDATIVE STRESS IN WOMEN WITH RECURRENT PYELONEPHRITIS
}

\author{
ДУ «Інститут нефрології НАМН України»
}

\section{SI «Institute of Nephrology of the National Academy of Medical Sciences»}

Ключові слова: лактобактеріi, кишківник, оксидативний стрес, рецидивуючий пієлонефрит.

Keywords: lactobacilli, intestine, oxidative stress, recurrent pyelonephritis.

Резюме. Метою нашої роботи було дослідити інтенсивність оксидативного стресу залежно від вмісту Lactobacillus spp. у загальній бактеріальній масі товстого кишківника хворих на рецидивуючий пієлонефрит.

Матеріал та методи. До одномоментного обсерваційного дослідження залучено 60 хворих на хронічну хворобу нирок (ХХН) I-II стадії: неускладнений пієлонефрит з рецидивуючим перебігом жіночої статі, віком 39,5 \pm 3,2 р. Залежно від кількості визначених у фекаліях лактобактерій, пацієнтки були розподілені на 2 групи: I група $(n=34)$ - пацієнтки з дефіцитом лактобактерій у складі мікробіоти кишківника, II група (n= 26) - хворі з нормальним вмістом лактобактерій. Інтенсивність перикисного окислення ліпідів (ПОЛ) оцінювали шляхом визначення вмісту малонового діальдегіду (МДА) в крові. Антиоксидантний захист (АОЗ) оцінювали за сумарною пероксидазною активністю (СПА) еритроцитів, ферменту-антиоксиданту иерулоплазміну (ЦП) та трансферину (Тр) в сироватці крові. Розраховували індекс оксидативного стресу (IОС)

Результати. Аналіз ПОЛ за вмістом МДА у біологічному матеріалі хворих визначив його статистично значуще підвищення у сироватці крові $(p=0,008)$ та сечі $(p=0,003)$ пацієнток з дефіцитом лактобактерій. Крім того, у пацієнток II групи визначено достовірне підвищення ІОС у сироватці крові $(p=0,03) ;$ рівень СПА, навпаки, був достовірно зниженим ( $p=0,02)$.

Висновки. Отримані результати підтверджують дані експериментальних досліджень щодо провідної ролі індигенної флори кишківника у розвитку оксидативного стресу.

Summary. The aim of our study was to investigate

Сташевська Наталя Вадимівна stashevskaja9@gmail.com the oxidative stress intensity depending on the content of Lactobacillus spp. in the colon of patients with recurrent pyelonephritis.

Material and methods. The observational study involved 60 women with chronic kidney disease (CKD) stage 
I-II: uncomplicated pyelonephritis, aged $39.5 \pm 3.2$ years. According to the quantitative content of Lactobacillus spp. in the patients' intestine, the women were allocated into two groups: the first group of the patients $(n=34)$ had a deficit of Lactobacillus spp. in the intestine, and the second one $(n=26)$ had a normal content of Lactobacillus spp. Along with the standard diagnostic methods, we defined the content of malondialdehyde levels in the serum (MDAs) and erythrocytes (MDAe) spectrophotometrically as an indicator of lipid peroxidation. Such parameters as the concentration of ceruloplasmin (CP), transferrin (TR) and sulfhydryl groups (SH-groups) in the blood and total peroxidase activity (TPA) in erythrocyte were studied as the indicators of antioxidant system. In addition, we calculated of oxidative stress index (OSI).

Results. The analysis of lipid peroxidation defined a significant increase of MDA level in the serum $(p=0.008)$ and urine ( $p=0.003$ ) of patients with deficit of intestine lactobacillus spp. Moreover, in the patients of Group II we observed the high level of serum OSI ( $p=0.03)$. By contrast, the TPA level was significantly reduced $(p=0.02)$.

Conclusions. The results of our work confirm the experimental studies data, which demonstrate the leading role of gut indigenous microbiota in the development of oxidative stress.

ВСТУП. Основою лікування інфекції сечової системи та пієлонефриту, зокрема, є антибактеріальні лікарські засоби $[2,5]$. Проте, їх постійне застосування, у тому числі й довготривала антибіотикопрофілактика у хворих на рецидивуючий пієлонефрит, може порушувати видовий та кількісний склад мікробіоти кишківника [6, 7, 10]. Індигенна мікрофлора бере участь у розщепленні білків, жирів і вуглеводів, створює умови для оптимального перебігу процесів травлення і всмоктування [9]. Деякі штами облігатної флори, такі як молочнокислі бактерії (Lactobacillus, Bifidobacterium, Bacteroides), синтезують бактеріоцини і молочну кислоту, які інгібують розмноження інших видів бактерій [8].

Бактерії сімейства Lactobacillus - непатогенні грампозитивні облігатні анаероби з високою ферментативною активністю. Середа їх існування - різні відділи шлунково-кишкового тракту, починаючи з ротової порожнини і закінчуючи товстим кишечником, де мешкають такі види лактобацил: Lactobacillus acidophilus, L.casei, L.bulgaricus, L.plantarum, L.salivarius, L.rhamnosus, L.reuteri [1]. У процесі життєдіяльності лактобактерії вступають у складні взаємини з іншими мікроорганізмами, в результаті чого пригнічуються гнильні та піогенні умовно-патогенні мікроорганізми, за рахунок здатності утворювати цілий ряд таких речовин, як молочна кислота, лізоцим, лактоцини В, F, J, M, лактоцидін і ацидолін, які володіють антибактеріальним ефектом [1, 8].

Разом $з$ тим, гомеостатичний контроль окислювально-відновного середовища, який здійснює епітелій кишківника, є балансом між перекисним окисленням ліпідів (ПОЛ) та антиоксидантним захистом (АО3) організму [4, 9].

Дослідження впливу мікробіоти кишківника на стан системи ПОЛ / АОЗ знаходяться у початковому стані та є поодинокими [9]. Тим не менш, деякі нещодавно опубліковані роботи відкрили шлях до ідентифікації взаємозв'язку між мікробіотою ШКТ та оксидативним стресом. Так, Ј. Хu зі співавторами експериментально продемонстрував негативний кореляційний зв'язок між інтенсивністю оксидативного стресу та складом мікрофлори кишківника тварин (з нормальним вмістом Lactobacillus і Bifidobacterium), а також позитивну кореляцію 3 надмірною кількістю кишкової палички [11]. Автори дійшли висновку, що нормальна мікрофлора товстої кишки грає вирішальну роль у захисті від кишкової інфекції за рахунок індукції прозапальних і прооксидантних реакцій, які контролюють навантаження патогенними мікроорганізмами [11, 12]. A. Mardinoglu зі співавторами повідомили про вплив кишкового біоценозу на метаболізм глутатіону в організмі [12]. Проте, розуміння сигнальних подій, ініційованих вільними радикалами, а також фізіологічної відповіді на такі процеси має ключове значення для поглиблення нашого розуміння участі мікрофлори ШКТ у ініціації оксидативного стресу з потенціалом для розробки нових терапевтичних втручань [4].

МЕТОЮ нашої роботи було дослідити інтенсивність оксидативного стресу залежно від вмісту Lactobacillus spp. у загальній бактеріальній масі товстого кишківника хворих на рецидивуючий пієлонефрит.

МАТЕРІАЛ ТА МЕТОДИ. До одномоментного обсерваційного дослідження залучено 60 хворих на хронічну хворобу нирок (XXН) I-II стадії: неускладнений пієлонефрит 3 рецидивуючим перебігом жіночої статі, віком від 19 до 68 років (у середньому $39,5 \pm 3,2$ р.). Тривалість захворювання пацієнток коливалась від півроку до 18 років та у середньому становила $6,0 \pm 4,1$ років. Кількість рецидивів на рік у середньому становила $6,2 \pm 1,9$.

Усі пацієнтки надали письмову інформовану згоду на участь у дослідженні. Протокол дослідження був схвалений локальною етичною комісією ДУ «Інститут нефрології НАМН України».

Інтенсивність ПОЛ оцінювали шляхом спектрофотометричного визначення вмісту малонового діальдегіду (МДА) в крові за методом Н. Д. Стальної. АОЗ оцінювали за сумарною пероксидазною активністю (СПА) еритроцитів, яку визначали визначали за реакцією з індигокарміном. Вміст у сироватці крові ферменту-антиоксиданту церулоплазміну (ЦП) визначали за реакцією з п-фенілендіаміндигідрохлоридом. Вміст трансферину (Тр) в сироватці крові - за реакцією з залізо-амоній цитратом. Розраховували індекс оксидативного стресу (IOC), як співвідношення сумарних змін активності оксидативних процесів до сумарного показника активності AO3 [3]. 
Бактеріологічне дослідження калу з визначенням кількісного та якісного складу мікробіоти товстого кишківника виконували у лабораторії «Сінево», свідоцтво про атестацію № ПТ - 120 / 12, видане 06.04.2012 р. та чинне до 05.04.2017.

Залежно від кількості визначених у фекаліях лактобактерій, пацієнтки були розподілені на 2 групи: I група - 3 дефіцитом лактобактерій у складі мікробіоти кишківника $(\mathrm{n}=34)$, II група - хворі 3 нормальним вмістом лактобактерій $(\mathrm{n}=26)$.

Статистичну обробку отриманих результатів проведено на персональному комп'ютері за допомогою програми «MedCalc» з урахуванням перевірки показників на нормальний розподіл з використанням критерію Колмогорова-Смірнова (dK-S).
За умов нормального розподілу оцінювали середні значення показників (М) та середнє квадратичне відхилення (SD); для їх порівняння використовували критерій Ст'юдента (kS). За невідповідності закону нормального розподілу для опису ознаки застосовували медіану $(\mathrm{Me})$ та інтерквартільний розмах [Q25-Q75]; для порівняльного аналізу застосовували непараметричний (U-критерій) Манна-Уїтні.

РЕЗУЛЬТАТИ ДОСЛІДЖЕННЯ ТА ЇХ ОБГОВОРЕННЯ. Аналіз ПОЛ за вмістом МДА у біологічному матеріалі хворих визначив його статистично значуще підвищення у сироватці крові та сечі пацієнток з дефіцитом лактобактерій (І група) (табл. 1, рис. 1).

Таблиия 1

Показники оксидативного стресу залежно від вмісту лактобактерій у товстому кишківнику хворих на рецидивуючий пієлонефрит

\begin{tabular}{|c|c|c|c|}
\hline Показник & I група $(\mathrm{n}=34)$ & II група $(n=26)$ & $\mathbf{P}$ \\
\hline \multicolumn{4}{|c|}{ Me [Q25-Q75] } \\
\hline МДАс (мколь/л) & $451[360-533,7]$ & $335[279,7-427,6]$ & 0,008 \\
\hline МДАе & $547,2[479-707,3]$ & 617,3 [440-707] & 0,93 \\
\hline МДАсечі & $3,8[2,2-6]$ & $1,9[1,06-2,6]$ & 0,003 \\
\hline СПА & $7,2[2,4-10,3]$ & $11,2[3,0-14,7]$ & 0,02 \\
\hline СПАсечі & $2,7[2,1-4,2]$ & $2,8[3,1-4,7]$ & 0,7 \\
\hline $\mathrm{SH}$ & $0,53[0,4-0,65]$ & $0,51[0,35-0,74]$ & 0,86 \\
\hline ЦП сечі & $1,8[1,5-1,95]$ & $1,7[1,5-2,04]$ & 0,45 \\
\hline \multicolumn{4}{|c|}{$\mathrm{M} \pm \mathrm{SD}$} \\
\hline IOC (ум. од.) & $4,4 \pm 1,8$ & $3,4 \pm 1,5$ & 0,03 \\
\hline ЦП сироватки & $0,017 \pm 0,02$ & $0,022 \pm 0,02$ & 0,54 \\
\hline
\end{tabular}

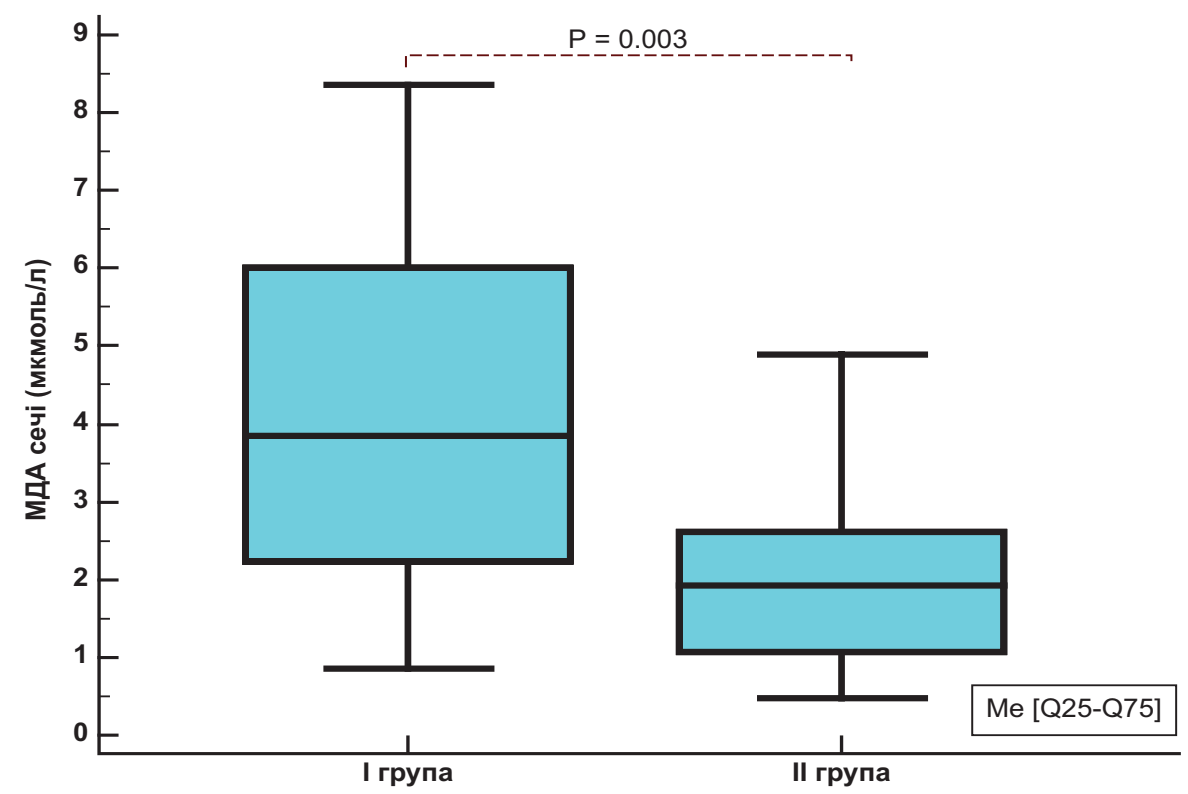

Рис. 1. МДА сечі залежно від вмісту лактобактерій у товстому кишківнику хворих на рецидивуючий пієлонефрит. 
Крім того, у пацієнток I групи визначено достовірне підвищення IOC у сироватці крові

(рис. 2). Рівень СПА, навпаки, був достовірно зниженим (див. табл. 1).

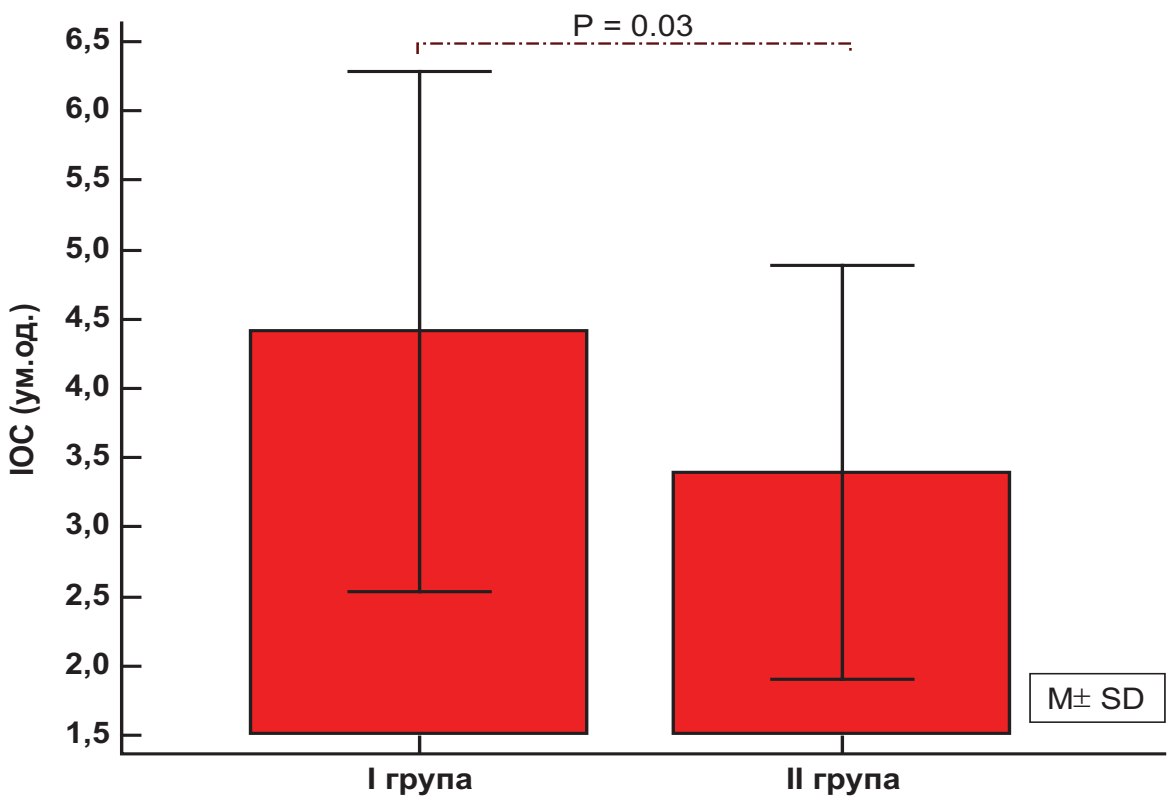

Рис. 2. ІОС у сироватці крові залежно від вмісту лактобактерій у товстому кишківнику хворих на рецидивуючий пієлонефрит.

Однофакторний регресійний аналіз засвідчив достовірний вплив дефіциту лактобактерій у кишківнику хворих на інтенсивність оксидативного стресу: рівняння регресії - у $=3,5379+0,7668$ х; коефіцієнт регресії - 3,5 \pm 0,36; $95 \%$ ДІ - 2,8-4,3; P 0,0001 .

ВИСНОВКИ. Таким чином, отримані нами результати підтверджують дані експериментальних досліджень щодо провідної ролі індигенної флори кишківника у розвитку оксидативного стресу. У хворих на рецидивуючий пієлонефрит з дефіцитом лактобактерій у складі мікробіоти кишківника спостерігається достовірно вища інтенсивність оксидативного стресу та зниження АОЗ за даними СПА.

\section{ЛІТЕРАТУРА:}

1. Ершова И. Б. Значение лактобактерий в организме человека и тактика правильного выбора эубиотика / И. Б. Ершова, Л. И. Гаврыш, Е. Н. Кунегина, А. А. Мочалова // Здоровье ребенка. - 2008. - № 1 (10). - С. 51-54.

2. Колесник М. О. Патогенез пієлонефриту: що ми знаємо і що ні / М. О. Колесник, Н. М. Степанова, В. Є. Дріянська, А. В. Руденко, Н. А. Калініна, В. Т. Кругліков // Український журнал нефрології та діалізу. - 2011. - № 3 (31). C. $34-46$.

3. Король Л. В. Біохімічні методи оцінки оксидативного статусу у хворих на хронічну хворобу нирок: Методичні рекомендації / Л.В. Король, Л.Я. Мигаль, Г.Г. Нікуліна, М.О. Колесник . Київ, 2013. - 30с.
4. Сircu M. L. Intestinal redox biology and oxidative stress / Circu M. L., Aw T. Y. // Semin Cell Dev Biol. - 2012. - V. 23. - P. 729-737.

5. Guidelines on Urological Infections // M. Grabe (Chairman), M. C. Bishop, T. E. BjerklundJohansen [et al.] // European Association of Urology. - 2013.

6. Jandhyala $S$. M. Role of the normal gut microbiota / Jandhyala S. M., Talukdar R., Subramanyam C., Vuyyuru H., [et al] // World Journal of Gastroenterology: WJG. - 2015. - V. 21 (29). P. 8787-8803.

7. Mikkelsen K. H. Effect of Antibiotics on Gut Microbiota, Gut Hormones and Glucose Metabolism (Electronic resource) / Mikkelsen K.H., Frost M., Bahl M. I, [et al.] // PLoS ONE. - 2015. - V. 10(11) - Mode of access: 1http://www.ncbi.nlm.nih.gov/ pmc/articles/PMC4643023/ .

8. Nobuhiko Kamada. Control of Pathogens and Pathobionts by the Gut Microbiota / Nobuhiko Kamada, Grace Y. Chen, Naohiro Inohara, Gabriel Núñez // Nat Immunol. - 2013. - V. 14(7). P. 685-690.

9. Núria Macha. Endurance exercise and gut microbiota: A review (Electronic resource) / Núria Macha, Dolors Fuster-Botellaa // Journal of Sport and Health Science. - 2016. - Mode of access : http://www.sciencedirect.com/science/article/pii/ S2095254616300163

10. Panda $S$. Short-term effect of antibiotics on human gut microbiota (Electronic resource) / Panda S., 
Elkhader I., Casellas F., López Vivancos J., [et al.] // PLoS One. - 2014. - V. 9 (4). - Mode of access: http://www.ncbi.nlm.nih.gov/pmc/articles/ PMC3991704

11. Regulation of an antioxidant blend on intestinal redox status and major microbiota in early weaned piglets / J. Xu, C. Xu, X. Chen, X. Cai, S. Yang, Y. Sheng, et al. // Nutrition. - 2014. - V. 30. P. 584-589.
12. The gut microbiota modulates host amino acid and glutathione metabolism in mice (Electronic resource) / Mardinoglu A., Shoaie S., Bergentall M., [et al.] / Molecular Systems Biology. - 2015. V. 11 (10). - Mode of access : https://www.ncbi. nlm.nih.gov/pmc/articles/PMC4631205/

Надійшла до редакції 27.01.2017

Прийнята до друку 15.02.2017

(c) Колесник М. О., Дріянська В. Є., Величко М. Б., Драннік Г. М., Петрина О. П., Непомнящий В. М., 2017 УДК: 612.017.1:616.611-002-036.12+616.61-008.6

М. О. КОЛЕСНИК, В. Є. ДРІЯНСЬКА, М. Б. ВЕЛИЧКО,

Г. М. ДРАННІК, О. П. ПЕТРИНА, В. М. НЕПОМНЯЩИЙ

\section{АСОЦІАТИВНІ ЗВ'ЯЗКИ НLА З ВИСОКИМ РІВНЕМ ПРОЗАПАЛЬНИХ ЦИТОКІНІВ КРОВІ У ХВОРИХ НА ГЛОМЕРУЛОНЕФРИТ}

\section{KOLESNYK, V. DRIYANSKA, M. VELYCHKO, G. DRANNIK, O. PETRINA, V. NEPOMNYASCHIY \\ ASSOCIATION OF HLA AND PROINFLAMMATORY CYTOKINES OF BLOOD IN PATIENTS WITH GLOMERULONEPHRITIS}

Державна установа «Інститут нефрології Національної академії медичних наук України»

$$
\text { SI “Institute of Nephrology NAMS of Ukraine” }
$$

Ключевые слова: антигены гистосовместимости, провоспалительные цитокины, хронический гломерулонефрит, нефротический синдром.

Key words: HLA, proinflammatory cytokines, chronic glomerulonephritis, nephrotic syndrome.

Резюме. Вступление. Цитокины и НLА играют вахную роль в иммуногенезе многих заболеваний, поэтому анализ этих показателей и их ассоциативных связей у больных гломерулонефритом (ГН) может определить их значение как дополнительных прогностических маркеров.

Цель работы - определить особенности ассоциаций высокого уровня сывороточных провоспалительных цитокинов (TNF $\alpha, M C P-1, I L-18)$ и определенных HLA в фенотипе для дальнейшего обоснования иммуногенеза хронического гломерулонефрита с нефротическим синдромом (ХГН, НС) и установления дополнительных маркеров прогнозирования его течения.

Материалы и методы. Изучали распределение НLA-антигенов у 264 больных с ХГН, НС и 350 здоровых доноров путем типирования лимфоцитов с помощью стандартного микролимфоцитотоксического теста (Терасаки). Методом ИФА исследовали в сыворотке крови уровень МCP-1 у 39, IL-18 - 40 та TNF- $\alpha$ - 96 больных («Invotrogen», «Вектор Бест», РФ).

Результаты. Показана ассоциация у взрослых больных ХГН, HC с HLA-A23, -24, -B8, -38, -41, -44, -DR1, -4, -w52 (RR 2); причинная роль с абсолютным риском (AP, $\sigma \geq 0,1)$ установлена для HLA-A24, -B8, -DR 1, -4, -w52. Относительный риск (ОР) развития хронической почечной недостаточности (ХПН) высокий при наличии в фенотипе HLA-10, -29, -30, -41, -51, -DR4; AP - HLA-A10.

У пациентов с ХГН, НС достоверно повышены уровни сывороточных провоспалительных иитокинов TNF-б, IL-17, MCP-1, которые наиболее высоки для TNF- $\alpha$ при наличии в фенотипе HLA-A23, -A28, -B44(OP ХГН, НС), -А10 (АР ХПН), для IL-18-A24 (АР ХГН, НС) и А10(АР ХПН). МСР-1 наиболее высокий у взрослых носителей антигенов риска ХГН, НС - относительного В41 и абсолютного - А28, В8, а также предиктора развития ХПН В41, что можно учитывать как прогнозонегативный маркер.

Заключение. Установлены ассоциации между сывороточными уровнями некоторых цитокинов и HLA у больных ХГН, НС. Считаем иелесообразным изучать HLA и провоспалительныу цитокины TNF- $\alpha, I L-18$ и

Дріянська Вікторія Евгенівна kirin@inephrology.kiev.ua
МСР-1 в крови в качестве дополнительных негативных прогностических предикторов для дифференцированного подхода клечению. 